\title{
PYROLYSIS OF EMPTY FRUIT BUNCHES: INFLUENCE OF TEMPERATURE ON THE YIELDS AND COMPOSITION OF GASEOUS PRODUCT
}

\author{
Mohamad Azri Sukiran, Loh Soh Kheang, Nasrin Abu Bakar and Choo Yuen May \\ Engineering and Processing Division, Malaysian Palm Oil Board, No. 6, \\ Persiaran Institusi, Bandar Baru Bangi, 43000, Kajang, Selangor, Malaysia
}

Received 2013-10-31; Revised 2013-11-11; Accepted 2014-02-03

\begin{abstract}
With the increasing concern on fossil fuel depletion and environmental problems, the utilization of renewable biomass resources is expected to play an important role in the future. Biomass can be converted into a variety of fuels and chemicals by different processes; one of which is pyrolysis that has been subjected to extensive research in recent years. In this study, pyrolysis of oil palm Empty Fruit Bunches (EFB) was investigated using a quartz fluidised-fixed bed reactor. The effects of pyrolysis temperatures on the yields and composition of gaseous products were investigated. The temperatures of pyrolysis used were in the range of $300-600^{\circ} \mathrm{C}$. The gaseous products from pyrolysis of (EFB) were analyzed using a dual-channel micro-GC with Thermal Conductivity Detector (TCD). The highest and lowest gas yields obtained were 42.98 and $31.55 \%$ at 600 and $300^{\circ} \mathrm{C}$, respectively. The gases detected were Carbon Monoxide $(\mathrm{CO})$, carbon dioxide $\left(\mathrm{CO}_{2}\right)$, Methane $\left(\mathrm{CH}_{4}\right)$, Ethane $\left(\mathrm{C}_{2} \mathrm{H}_{6}\right)$ and Ethylene $\left(\mathrm{C}_{2} \mathrm{H}_{4}\right)$. At 300 and $400^{\circ} \mathrm{C}$, the gas mixture comprised mainly $\mathrm{CO}_{2}(20 \%)$ and $\mathrm{CO}$ (20\%). Other gases such as $\mathrm{CH}_{4}, \mathrm{C}_{2} \mathrm{H}_{4}$ and $\mathrm{C}_{2} \mathrm{H}_{6}$ only evolved at higher temperature starting from $400^{\circ} \mathrm{C}$ with the yield of the latter two gases in very low concentration.
\end{abstract}

Keywords: Empty Fruit Bunches (EFB), Pyrolysis, Gas Yields, Biomass

\section{INTRODUCTION}

At present, large area of land in Malaysia is cultivated with oil palm. The plantations and the mills can supply massive quantities of biomass as a raw materials for generating renewable energy needed by conversion in needs of modern society. It is an alternative source of renewable energy that would help us to conserve our fossil fuel reserves for the use of future generations thus enabling us to promote sustainable development. The various oil palm biomass resources available for the oil palm industry are Empty Fruit Bunch (EFB), fruit fiber, palm shell, palm kernel, palm fronds and trunks amounting to about about 80 million tonnes (dry basis). Hence,
Malaysia has the potential to utilize these biomass resources efficiently and effectively for value addition (Sukiran et al., 2011; Khor et al., 2009).

Currently the interest in pyrolysis is rapidly growing using the thermal degradation reaction which converts biomass into various products such as bio-oil, char and gases in the absence of oxygen (Sukiran et al., 2009). During pyrolysis, the successive reactions that can occur are cracking, isomerization, dehydrogenation and aromatization. The resulting products are gases i.e., $\mathrm{H}_{2}$, $\mathrm{CO}, \mathrm{CO}_{2}, \mathrm{CH}_{4}$ and $\mathrm{C}_{2} \mathrm{H}_{4}$, char, some organic compounds and bio-oil. Gaseous product and bio-oil are normally collected during the pyrolysis reaction while the remaining carbon residue in the form of char is deposited in the reactor tube.

Corresponding Author: Mohamad Azri Sukiran, Engineering and Processing Division, Malaysian Palm Oil Board, No.6, Persiaran Institusi, Bandar Baru Bangi, 43000, Kajang, Selangor, Malaysia 
So far, most of the investigations focused on the effects of various parameters (temperature, heating rate, pressure, particle size) on the distribution and the characterization of pyrolysis products (Acikalin et al., 2012). Only few studies were found focusing on the real time analysis of gases released during pyrolysis of agricultural residues. The lack of data combined with the large variety and complexity of agricultural residues have led to difficulties in understanding the characteristics and formation mechanisms of gas products during the pyrolysis of agricultural residues (Peng et al., 2012). The investigation on the release properties of the released products and the mechanism of the gas formation is essential in order to achieve high yields of the targeted products.

The composition of the gas mixture is highly influenced by the pyrolysis temperature as it is an important variable in the thermal decomposition processes of the biomass and as such exerts considerable influence on the product distribution. The increase in the reaction temperature can lead to a significant increase in the gas yield. Moreover, high heating rate results in much higher gas yield. It is a known fact that a high heating rate is beneficial for gas production. However, in normal circumstances the heating rate is not very pronounced. The major components of the gas mixture produced from the experiment are $\mathrm{CO}_{2}, \mathrm{CO}$ and $\mathrm{H}_{2}$ (Tihay and Gillard, 2010; Ouiminga et al., 2009).

Pyrolysis gas consisting of $\mathrm{H}_{2}, \mathrm{CO}$ and $\mathrm{CO}_{2}$ when converted to syn-fuel, can be beneficial to the environment, as it is sulfur free, contais oxygenates resulting in in less $\mathrm{CO}$ and ozone emissions to the atmosphere (Onal et al., 2011). Furthermore, through various technologies, fuels of widely varying compositions can be selectively synthesized to give high engine performance characteristics and energy efficiencies (Imam and Capareda, 2012).

In this study, EFB was fed into a fluidized fixed bed reactor under different pyrolysis temperatures and the gas products obtained were characterised using GC.

\section{MATERIALS AND METHODS}

\subsection{Pyrolysis Experiments}

The EFB was dried at $103^{\circ} \mathrm{C}$. It was ground and sieved repeatedly to obtain the optimum size ranging from 91-106 $\mu \mathrm{m}$ for the pyrolysis experiment. Pyrolysis of the oil palm EFB was carried out using a fluidised-fixed bed quartz reactor. An electric furnace heated the reactor spanning a length of $135 \mathrm{~mm}$ and an inner diameter of $40 \mathrm{~mm}$. The temperature of the reactor was determined by inserting a thermocouple as near the upper fritz as possible. The whole experimental rig consisting of the volatiles and gas collection system is illustrated in Fig. 1.

The sand bed was fluidised using argon at a rate of $1.5 \mathrm{~L} \mathrm{~min}^{-1} .160 \mathrm{~g}$ zircon sand of $180-250 \mu \mathrm{m}$ was used as the sand bed. $2 \mathrm{~g}$ of EFB feedstock of particle size of 91-106 $\mu \mathrm{m}$ was introduced into the bed of zircon sand. The whole experiment must be held for either a minimum of $10 \mathrm{~min}$ or until no further significant release of gas was observed. The connection tubes between the reactor and the cooling system were heated using heating tape to avoid condensation of pyrolysis vapors.

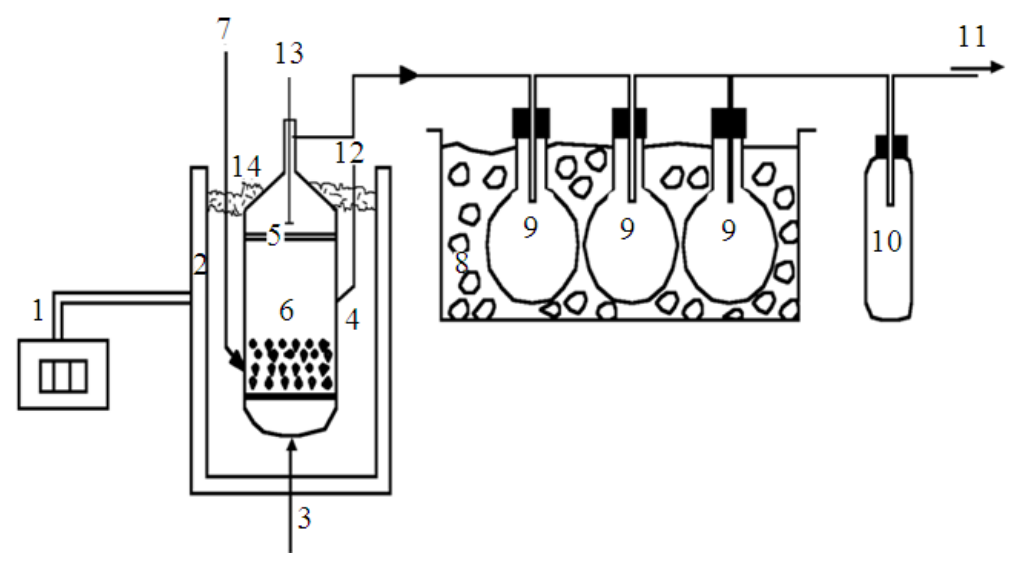

Fig. 1. Schematic Diagram of the Pyrolysis System (1)Temperature recorder; (2) Furnace; (3) Fluidizing Gas; (4) Reactor; (5) Quartz fritz; (6) Sand bed; (7) Feedstock inlet; (8) Water-ice bath; (9) Bio-oil collector; (10) Gas dryer; (11) Gas exit; (12) Sand feeder; (13) Thermocouple; (14) Glass wool 
Before each trial run, the reactor was weighed and after a run, the cooled reactor was weighted again and the char yield was calculated from the difference. The char remaining in the reactor was purged using argon into the sand bed. The bio-oil was then collected in flasks placed in a cold trap containing ice. The accumulated bio-oil collected in the flasks was subsequently transferred into a small bottle and the remaining liquid product in the flasks, including in all connection tubes, were dissolved with ethanol.

The solvent part of the bio-oil which is dissolved in ethanol was extracted in a rotary evaporator to establish the quality of the bio-oil. The bio-oil comprising a dark liquid was then weighed. After that, gas was intermittently trapped in a gas bottle as the temperature of the pyrolysis was increased. The gas yield was calculated from the material balance.

\subsection{Effect of Temperature}

A series of experiments were performed to determine the effect of the pyrolysis temperature on pyrolysis yields. The temperature was raised at $30^{\circ} \mathrm{C} \mathrm{min}^{-1}$ to a final temperature of either $300,400,500$ or $600^{\circ} \mathrm{C}$ with particle size of the EFB used varying from 91-106 $\mu \mathrm{m}$.

\subsection{Gas Analysis}

The gas products from the pyrolysis of oil palm EFB pyrolysis was analysed using a dual-channel micro-GC equipped with a Thermal Conductivity Detector (TCD). Channel A with Molecular Sieve 5A column (MS-5A) was set at $90^{\circ} \mathrm{C}$ for the determination of $\mathrm{H}_{2}, \mathrm{CO}$ and $\mathrm{CH}_{4}$ (methane). Channel B with Plot-U was set at $70^{\circ} \mathrm{C}$ for checking $\mathrm{CO}_{2}, \mathrm{C}_{2} \mathrm{H}_{4}$ and $\mathrm{C}_{2} \mathrm{H}_{6}$. A gas cylinder consisting of standard gas i.e., $\mathrm{CO}(0.1 \mathrm{~mol} \%), \mathrm{CO}_{2}(0.05 \mathrm{~mol} \%)$, $\mathrm{C}_{2} \mathrm{H}_{4}(0.05 \mathrm{~mol} \%), \mathrm{C}_{2} \mathrm{H}_{6}(0.05 \mathrm{~mol} \%)$ and $\mathrm{CH}_{4}(98.0$ mol\%) was purchased from Agilent company and the calibration was carried out regularly. The gas bottle collectors were purged with argon before used.

\section{RESULTS}

As shown in Fig. 2, at the lowest pyrolysis temperature of $300^{\circ} \mathrm{C}$, the decomposition process was relatively slow and char was the major product. As the temperature was increased from $300^{\circ} \mathrm{C}$ to $500^{\circ} \mathrm{C}$, the amount of condensable liquid product increased to a maximum value by $33-35 \%$. The gas yields were $31.55,38.97,39.69$ and 42.98 at temperature of 300 , 400,500 and $600^{\circ} \mathrm{C}$ respectively. The highest and lowest of gas yield obtained was 42.98 and $31.55 \%$ at the temperature of $600^{\circ} \mathrm{C}$ and $300^{\circ} \mathrm{C}$ respectively.

\subsection{Gas Analysis}

The distribution of gaseous products from pyrolyzing oil palm EFB mainly depends on reaction temperature. The gas species distribution profile obtained at different final temperatures is shown in Fig. 3 (area percentage based on 5 gases identified). The gases detected were $\mathrm{CO}, \mathrm{CO}_{2}, \mathrm{CH}_{4}, \mathrm{C}_{2} \mathrm{H}_{6}$ and $\mathrm{C}_{2} \mathrm{H}_{4}$. At the temperatures between 300 to $400^{\circ} \mathrm{C}$, the gas mixture mainly composed of $\mathrm{CO}_{2}, \mathrm{CO}$ and trace amount of $\mathrm{CH}_{4}$.

Increasing the temperature increased the release of $\mathrm{CH}_{4}$. As the temperature increased from $300^{\circ} \mathrm{C}$ to $500^{\circ} \mathrm{C}$, $\mathrm{CH}_{4}$ contents increased linearly with an increase in temperature, but start decreasing above $500^{\circ} \mathrm{C}$. After $600^{\circ} \mathrm{C}$, a second formation of $\mathrm{CH}_{4}$ occurred due to the lignin decomposition. As the temperature increased from $300^{\circ} \mathrm{C}$ to $600^{\circ} \mathrm{C}, \mathrm{CO}$ contents slightly decreased with an increased in temperature whilst. $\mathrm{C}_{2} \mathrm{H}_{4}$ and $\mathrm{C}_{2} \mathrm{H}_{6}$ contents were very low evolving only at temperature of $500^{\circ} \mathrm{C}$.

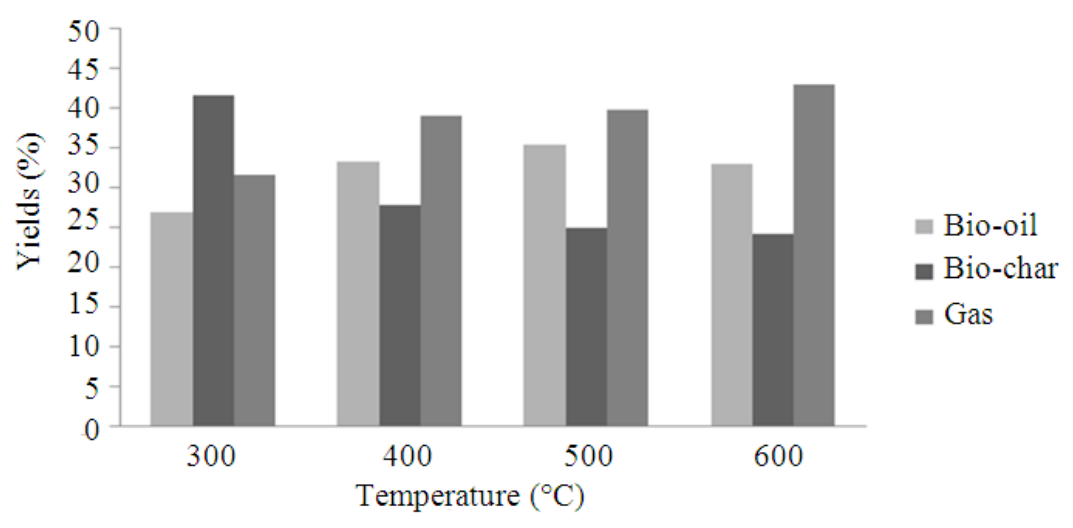

Fig. 2. Pyrolysis yields at different temperature 


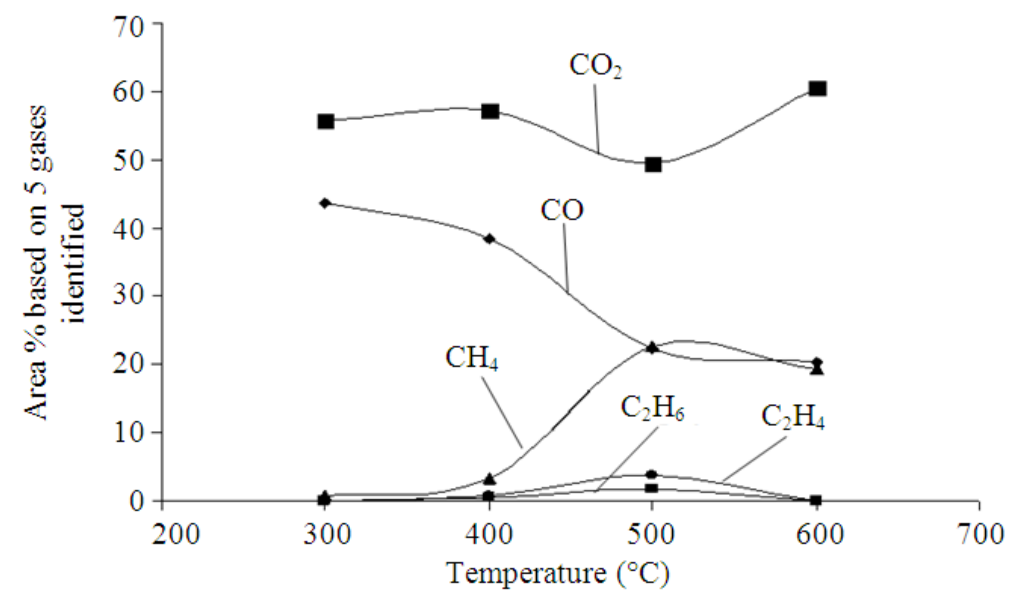

Fig. 3. Gases emitted as temperature was increases

\section{DISCUSSION}

The gas production rate increased with the increase in pyrolysis temperature. An increase in gas products is thought to occur predominantly due to the secondary cracking of the pyrolysis vapours at higher temperature. However, the secondary decompositions of the char at the higher temperatures may also give other noncondensable gas products (Sukiran et al., 2011).

The release of $\mathrm{CO}_{2}$ is mainly dependent on decomposition of cellulose and hemicellulose. On the other hand, $\mathrm{CO}_{2}$ evolution at higher temperature can be due to the lignin degradation. The $\mathrm{CO}_{2}$ content decreased as the temperature increased from 400 to $500^{\circ} \mathrm{C}$. After that, with the further rise in temperature it increased again from 50 to 60 of area percent based on 5 gases identified.

The formation of $\mathrm{CH}_{4}$ and other light hydrocarbons found could be mainly related to the degradation of lignin, since their concentration increased with the degradation processes at high temperatures. The formation of $\mathrm{CH}_{4}$ was due to the release of methoxy groups, involving $\mathrm{C}-\mathrm{C}$ rupture that was controlled by hydrogen transfer reactions.

The area percent of $\mathrm{C}_{2} \mathrm{H}_{4}$ and $\mathrm{C}_{2} \mathrm{H}_{6}$ decreased above $500^{\circ} \mathrm{C}$ due to the release of hydrogen at those temperatures. The $\mathrm{H}_{2}$ contents were not detected in this study as the production of $\mathrm{H}_{2}$ only occurred at high temperature possibly above $600^{\circ} \mathrm{C}$. The decrease in the percentage of area occupied by some components at high temperatures could be due to their conversion to other products (Wu et al., 2013; Dufour et al., 2009).

\section{CONCLUSION}

The study of the effect of temperature on gas yield had shown that a $600^{\circ} \mathrm{C}$ was the optimum temperature to produce gas yield (43\%). The gases detected were Carbon Monoxide (CO), Carbon Dioxide $\left(\mathrm{CO}_{2}\right)$, Methane $\left(\mathrm{CH}_{4}\right)$, Ethane $\left(\mathrm{C}_{2} \mathrm{H}_{6}\right)$ and Ethylene $\left(\mathrm{C}_{2} \mathrm{H}_{4}\right)$. The gaseous product from pyrolysis usually has a high level of hydrocarbons, particularly methane and saturated and unsaturated hydrocarbons from the complex thermal degradation processes. The gas may be used for feed drying, process heating, power generation or exported for sale.

\section{ACKNOWLEDGEMENT}

The researchers wish to thank the Director-General of the Malaysian Palm Oil Board (MPOB) for permission to publish this study. We would like to acknowledge all staff of the Energy and Environment Unit, MPOB, for their valuable assistance throughout the implementation of the projects.

\section{REFERENCES}

Acikalin, K., F. Karaca and E. Bolat, 2012. Pyrolysis of pistachio shell: Effects of pyrolysis conditions and analysis of products. J. Fuel, 95: 169-177. DOI: 10.1016/j.fuel.2011.09.037

Dufour, A., P. Girods, E. Masson, Y. Rogaume and A. Zoulalian, 2009. Synthesis gas production temperature on product distribution. Int. J. Hydrogen Energy, 34: 1726-1734. DOI: 10.1016/j.ijhydene.2008.11.075 
Imam, T. and S. Capareda, 2012. Characterization of bio-oil, syn-gas and bio-char from switchgrass pyrolysis at various temperatures. J. Anal. Applied Pyrol., 93: 170-177. DOI: 10.1016/j.jaap.2011.11.010

Khor, K.H., K.O. Lim and Z.A. Zainal, 2009. Characterization of bio-oil: A by product from slow pyrolysis of oil palm empty fruit bunches. Am. J. Applied Sci., 6: 1647-1652. DOI: 10.3844/ajassp.2009.1647.1652

Onal, P.O., B.B. Uzun and A.E. Putun, 2011. Steam pyrolysis of an industrial waste for bio-oil production. J. Fuel. Proces. Tech., 92: 879-885. DOI: $10.1016 /$ j.fuproc.2010.12.006

Ouiminga, S.K., T. Rogaume, M. Sougoti, J.M. Commandre and J. Koulidiati, 2009. Experimental characterization of gaseous species emitted by the fast pyrolysis of biomass and polyethylene. J. Anal. Applied Pyrol., 86: 260-268. DOI: 10.1016/j.jaap.2009.07.002

Peng, F., H. Song, X. Jun, S. Lushi and S. Sheng, 2012. Study on the gas evolution and char structural change during pyrolysis of cotton stalk. J. Anal. Applied Pyrol., 97: 130-136. DOI: 10.1016/j.jaap.2012.05.012
Sukiran, M.A., M.C. Chow and N.K. Abu Bakar, 2009. Bio-oils from pyrolysis of oil palm empty fruit bunches. Am. J. Applied Sci., 6: 869-875. DOI: 10.3844/ajassp.2009.869.875

Sukiran, M.A., S.K. Loh, A.B. Nasrin and Y.M. Choo, 2011. Production and characterization of bio-char from the pyrolysis of empty fruit bunches. Am. J. Applied Sci., 8: 984-988. DOI: 10.3844/ajassp.2011.984.988

Tihay, V. and P. Gillard, 2010. Pyrolysis gases released during the thermal decomposition of three Mediteranean species. J. Anal. Applied Pyrol., 88: 168-174. DOI: 10.1016/j.jaap.2010.04.002

Wu, C., Z. Wang, J. Huang and P.T. Williams, 2013. Pyrolysis/gasification of cellulose, hemicellulose and lignin for hydrogen production in the presence of various nickel-based catalysts. J. Fuel., 106: 697706. DOI: 10.1016/j.fuel.2012.10.064 